\title{
Two decades of change in state, pressure and conservation responses in the coastal forest biodiversity hotspot of Tanzania
}

\author{
Neil D. Burgess, Isaac Malugu, Peter Sumbi, Almas Kashindye, Adam Kijazi \\ Karyn Tabor, Boniface Mbilinyi, Japhet Kashaigili \\ Timothy Maxhell Wright, Roy E. Gereau, Lauren Coad, Kathryn Knights \\ Jamie Carr, Antje Ahrends and Rebecca L. Newham
}

\begin{abstract}
We present an analysis of changes of state, pressures and conservation responses over 20 years in the Tanzanian portion of the Coastal Forests of Eastern Africa biodiversity hotspot. Baseline data collected during 19891995 are compared with data from a synthesis of recently published papers and reports and new field work carried out across the region during 2010-2014. We show that biodiversity endemism values are largely unchanged, although two new species (amphibian and mammal) have been named and two extremely rare tree species have been relocated. However, forest habitat continues to be lost and degraded, largely as a result of agricultural expansion, charcoal production to supply cities with cooking fuel, logging for timber and cutting of wood for firewood and building poles. Habitat loss is linked to an increase in the number of species threatened over time. The government-managed forest reserve network has expanded slightly but has low effectiveness. Three forest reserves have been upgraded to National Parks and Nature Reserves, which have stricter protection and more effective enforcement. There has also been rapid development of village-owned forest reserves, with more than 140 now existing; although usually small, they are an important addition to the areas being managed for sustainable resource use, and also provide tangible
\end{abstract}

NeiL D. Burgess ${ }^{\star}$ (Corresponding author) and RebecCa L. Newham UNEPWCMC, 219 Huntingdon Road, Cambridge CB3 0DL, UK

E-mail neil.burgess@unep-wcmc.org

Isaac Malugu, Peter Sumbi, Almas Kashindye, Adam KiJazi WWF Tanzania Country Programme Office, Tanzania

Karyn TABor and Timothy MaXwell Wright Conservation International, Washington, DC, USA

Boniface Mbilinyi and Japhet Kashaiglli Sokoine University of Agriculture, Morogoro, Tanzania

Roy E. Gereau Missouri Botanical Garden, St. Louis, Missouri, USA

LAUREN COAD University of Oxford, UK

Kathryn Knights Protected Area Solutions, Sheffield, UK

Jamie Carr IUCN Global Species Programme, Cambridge, UK

AntJe Ahrends Royal Botanic Garden Edinburgh, UK

${ }^{*}$ Also at: CMEC, Natural History Museum, Copenhagen, Denmark

Received 14 March 2015. Revision requested 3 June 2015.

Accepted 28 July 2015. First published online 11 March 2016. benefits to local people. Human-use pressures remain intense in many areas, and combined with emerging pressures from mining, gas and oil exploration, many endemic species remain threatened with extinction.

Keywords Biodiversity, coastal forest, conservation responses, pressures, protected areas, Tanzania

To view supplementary material for this article, please visit http://dx.doi.org/10.1017/So03060531500099X

\section{Introduction}

uch has changed in Tanzania over the past 20 years. 1 Tanzania is now Africa's 12th largest economy, with an annual growth of $7.2 \%$, and attracts an increasing amount of both domestic and foreign private investment. There has been rapid economic development and urbanization, with human population growth of c. $3 \%$ per annum, and the emergence of mining, gas and oil industries (UNDP et al., 2013). Moreover, conservation itself has changed. The World Bank and IMF promoted structural adjustment programmes in Tanzania, which greatly reduced government capacity for forest protection in the late 1990s. Since then, partly as a response to these changes, new conservation policies and laws have been developed, promoting communitybased forest management and co-management between communities and government institutions (Blomley et al., 2008). Market-based conservation tools, such as payment for ecosystem services schemes (REDD+ for climate mitigation and Payments for Water Services) have been piloted (Burgess et al., 2010; Lopa et al., 2012), and sustainable timber harvesting and charcoal production have been championed as a source of income for communities (Treue et al., 2014).

The terrestrial coastal forests of Tanzania are part of the Coastal Forests of Eastern Africa biodiversity hotspot, one of the highest priority areas for conservation (Mittermeier et al., 2004). Burgess \& Clarke (2000) summarized available information on the state of biodiversity and habitat in these forests and the pressures they were facing, based on surveys conducted during 1989-1995. Since then there have been 
partial updates on biological values (Burgess et al., 2003), detailed pressure studies (Milledge et al., 2007; Ahrends et al., 2010), and the development of conservation plans (Salehe et al., 2006; UNDP-GEF, 2008). All studies have shown that the coastal forests are globally outstanding for biodiversity (Burgess et al., 1998, 2004; WWF, 2011) but face considerable threats from conversion to farmland and exploitation of resources for traded products such as charcoal and timber, and subsistence products such as firewood and poles for house construction (Burgess et al., 2004).

Here we provide an update on the state, pressures and responses to conservation of the globally important coastal forests of Tanzania, and summarize changes that have occurred over the past 20 years and we believe will continue as Tanzania develops.

\section{Methods}

\section{State of biodiversity}

Baseline biodiversity data (1989-1995) are based largely on data collected in 83 Tanzanian coastal forests and on a review of relevant documents and literature. These data are summarized in Burgess \& Clarke (2000) and Burgess et al. (2003, 2004), and are henceforth referred to as baseline 1995. The changes in biodiversity up to 2014 were compiled from a combination of sources, including Azeria et al. (2007), Wegner et al. (2006, 2009), and field work undertaken in 2011 by Tanzanian experts from the University of Dar es Salaam, focused on poorly known forests of the Kilwa region (Howell et al., 2011) and on Zanzibar (Siex, 2011). Some data are from assessments of reptiles and plants for the IUCN Red List (reptiles, J. Carr; plants, R. Gereau; IUCN, unpubl. data).

\section{Pressures on biodiversity}

All remotely sensed forest/tree cover data used are based on Landsat imagery. Baseline forest cover data from c. 1990 are from Tabor et al. (2010), forest losses until 2007 from Godoy et al. (2011), and tree cover and forest and woodland status and loss until 2010 from Hansen et al. (2013), updated by Tabor et al. (2015).

Limited baseline data on degradation pressures on these forests (e.g. charcoal production, logging, and collections of wood for fuel and building poles) were obtained from Burgess \& Clarke (2000). Data on changes in degradation pressures were compiled using publications from the mid 2000s (Ahrends, 2005; Milledge et al., 2007; Ahrends et al., 2010), post 2010 (Shemdoe \& Abdalah, 2011; Abdalah et al., 2012; Sulle, 2013), and the authors' personal observations in forests in the districts of Lindi, Kilwa (Lindi region) and Rufiji (Coast region) during 2013-2014. Field research on the amounts and profitability of forest exploitation (timber, charcoal and firewood sales) in the coastal forests was conducted in 2012 in 480 households in 18 coastal forest villages across the Coast, Lindi and Tanga regions; discussions were also held with an additional 180 key informants (Supplementary Table S1; Abdalah et al., 2012).

\section{Conservation response}

The main conservation response in these forests has been the creation of protected areas of various types, including state and non-state-managed reserves. We take an inclusive view of protected areas and include National Parks and Game Reserves, together with Central Government Forest Reserves and Local Authority Forest Reserves (Burgess et al., 2007), Village Land Forest Reserves (Blomley et al., 2008), Marine Parks and Reserves, and Forest Nature Reserves. Baseline information on the protected area network is from Burgess \& Clarke (2000). Information on changes up to 2014 was obtained through literature review, site visits to offices of the Tanzanian Forest Service in Dar es Salaam and local government District Forest Offices along the coast of Tanzania, and discussions in villages in each district (Harrison et al., 2011; Kashaigili et al., 2011), updated by the authors in 2013-2014.

There are no baseline data on the effectiveness of protected area management in terms of management inputs and quality, although there is some information on the staffing available to the forest sector before and after the structural adjustment programmes of the late 1990s (Burgess \& Clarke, 2000). We assessed the effectiveness of management of many reserves along the coast, starting in 2003, using the Management Effectiveness Tracking Tool (METT; Belokurov et al., 2009; Leverington et al., 2010). An assessment of $>100$ sites was conducted in 2011, encompassing National Parks, Central Government Forest Reserves, Local Authority Forest Reserves and Village Land Forest Reserves (Harrison et al., 2011), and > 50 assessments were undertaken during 2012-2014. We used data collected during 2003-2006 for sites where more recent assessments were not available (authors' compilation of METT data). Where multiple assessments had been undertaken for a given reserve, we assessed change in effectiveness over time; for other analyses we used the most recent assessment available.

\section{Results}

State of biodiversity

The coastal forests of Tanzania support many endemic and near-endemic species of fauna and flora (Supplementary Tables $S_{2} \& S_{3}$ ). Numbers of endemic vertebrate species 
in the coastal forests have changed little over the past decade; however, there was a slight increase in the number of known endemic species following taxonomic reassessments of the Zanzibar red colobus Procolobus kirkii and the description of new species of amphibian (Kassina jozani) on Unguja island and galago (Galagoides rondoensis) on the mainland. Some new plant species have also been described based on older collections; for example, Monodora carolinae Couvreur and Monodora hastipetala Couvreur in the southern coastal forests, and Aidia abeidii S.E. Dawson \& Gereau from the northern coastal forests and adjacent Eastern Arc Mountains (Couvreur et al., 2006; Dawson \& Gereau, 2010). One plant species that was categorized as Extinct on the 1998 Red List (Erythrina schliebenii Harms) and another categorized as Critically Endangered that had not been recently recorded at its type locality in Kenya (Karomia gigas (Faden) Verdc.) were rediscovered in Kilwa during botanical surveys in 2011 (Clarke et al., 2011). Field work during 2005-2006 in Mtwara (Wegner et al., 2006, 2009), and during 2011-2012 in Coast (Rufiji) and Lindi (Kilwa and Lindi) (Howell et al., 2011) enhanced knowledge of these poorly known forests but no new species were discovered.

Current knowledge suggests there are five endemic and 22 near-endemic bird species, five endemic and 14 nearendemic mammals (plus another possible endemic species), six endemic amphibian species, and three endemic and 13 near-endemic reptile species (Broadley, 2003; IUCN, unpubl. data; Supplementary Table S2). There are 325 vascular plant taxa (264 species, 31 subspecies, 30 varieties) endemic to the Coastal Forests of Eastern Africa biodiversity hotspot within Tanzania (Supplementary Table $S_{3}$ ), and 349 near-endemic taxa (269 species, 45 subspecies, 34 varieties, 1 forma), i.e. those confined to the Coastal Forests hotspot and one or more of the Eastern Arc Mountains, the Lake Nyasa Climatic Region (Gereau et al., 2012), and the Neogene Volcanics of Tanzania (Supplementary Table S3), yielding a total of 674 endemic and near-endemic plant taxa.

Since the baseline period there has been an increase in the number of species assessed for the IUCN Red List. Many of the coastal forest endemic or near-endemic vertebrates are under threat: 12 of the 27 bird species are categorized as Near Threatened or with a higher status of threat, as are 13 of 20 mammals, four of six amphibians and eight of 16 reptiles (of which four have not yet been evaluated; Supplementary Table S2). Two mammal species, the Aders' duiker Cephalophus adersi and the rondo galago Galagoides rondoensis, are categorized as Critically Endangered. On the 2015 IUCN Red List 261 endemic or near-endemic vascular plant taxa of the coastal forests of Tanzania were categorized as Near Threatened or in one of the higher categories of threat, with 18 categorized as Critically Endangered (Supplementary Table $\mathrm{S}_{3}$ ). The main threats are the small extent of remaining habitat and the ongoing loss and degradation of forest areas.

Other threatened species that are not endemic to the region but inhabit coastal forests and associated habitats include the elephant Loxodonta africana, lion Panthera leo and hippopotamus Hippopotamus amphibius, which are threatened by hunting. Among the vascular plants, 43 taxa that are not endemic or near-endemic appeared in Near Threatened or threatened categories on the 2015 IUCN Red List, 36 of these being more widespread in continental Africa and seven occurring outside Africa, mostly in Madagascar and the Mascarenes. Although some of these taxa are probably genuinely threatened with extinction, a large proportion of them were assessed only under the previous Red List Categories v. 2.3 (IUCN, 1994) and therefore need to be reassessed under the current Categories and Criteria v. 3.1 (IUCN, 2012), as emphasized by Gereau et al. (2014) for the broader Eastern Arc Mountains and Coastal Forests Region.

\section{Pressures on biodiversity}

Forest loss Forest is lost primarily through conversion to farmland, mainly through shifting cultivations. Overall, coastal forest cover declined by over a third from 420,765 ha in 1990 to 358,333 ha in 2000 and to 273,709 ha in 2007 . The rate of deforestation has been lower within reserves: 0.2 and $0.4 \%$ year $^{-1}$ during 1990-2000 and 2000-2007, respectively, compared to 1.3 and $0.6 \%$ year $^{-1}$ outside reserves during the same periods (Godoy et al., 2011). Analysis of the 2010 update using the data of Hansen et al. (2013; Fig. 1) shows that patterns of forest loss are concentrated around Dar es Salaam, with patchy forest loss elsewhere and with particularly heavy encroachment in Pugu-Kazimzumbwi and Vikindu forest reserves, for charcoal making and settlements (Malugu, 2012).

Charcoal In Burgess \& Clarke (2000) charcoal production was reported only in the forests within $10 \mathrm{~km}$ of Dar es Salaam (Pugu, Kazimzumbwe, Pande). Studies during 2004-2005 (Ahrends, 2005; Ahrends et al., 2010) showed that the forests around Dar es Salaam, which mainly lie within reserves, continued to be heavily degraded by conversion to charcoal and had lost much of their woody biomass. At that time c. $80 \%$ of the charcoal destined for Dar es Salaam was sourced from an area within a $50 \mathrm{~km}$ radius of the city (Ahrends, 2005). However, village surveys in 2012 showed that charcoal was being sourced from forests $>100 \mathrm{~km}$ south of Dar es Salaam (Abdalah et al., 2012), a trend that has continued (authors, pers. obs.). Despite the expansion of the charcoal-making area into forests further south of Dar es Salaam, production 

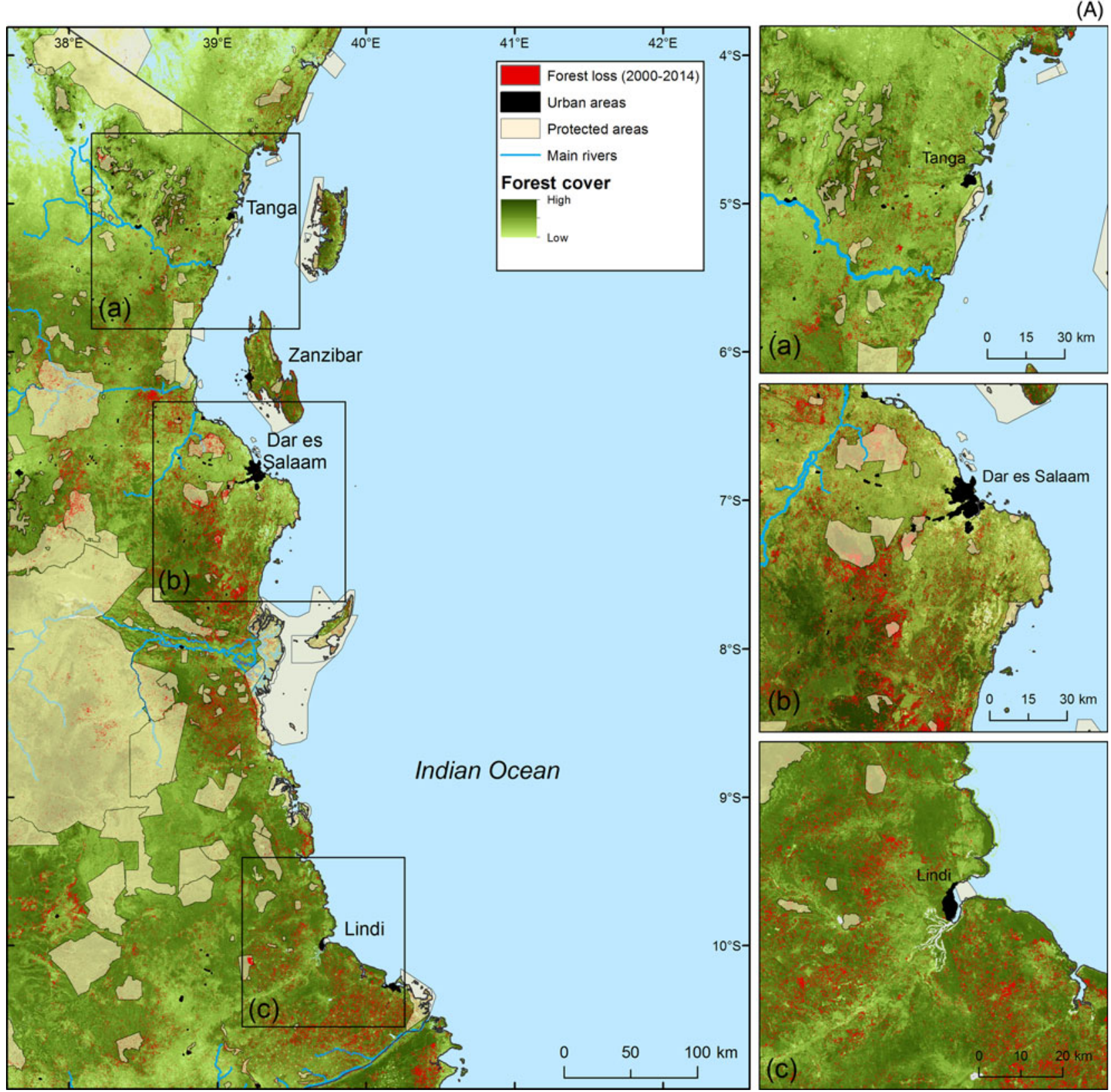

FIG. 1 Forest cover and forest loss in coastal Tanzania during 2000-2012. (A) Based on raw data from Hansen et al. (2013): (a) Forest change around the East Usambara-Tanga town area in northern Tanzania; (b) forest loss around the capital city, Dar es Salaam; (c) forest change in southern Tanzania, towards the Mozambique border. (B) Based on further analysis and processing to show forest, woodland and mangrove cover and loss and the major urban centres in the same coastal region of Tanzania (analysis from Tabor et al., 2015).

remains largely confined to areas within $30 \mathrm{~km}$ of the paved highway.

Timber The coastal forests and woodlands support high-value timber species that have been commercially logged over many years. During the baseline period high-value timber species were harvested: Milicia excelsa (mvule; Near Threatened), Khaya anthotheca (mkangazi;
Vulnerable), Brachylaena huillensis (muhuhu; Near Threatened) and Afzelia quanzensis (mkongo). The first three are now rare as a result of overharvesting. A survey of 18.1 ha across 10 coastal forests conducted in 2004-2005 found only one sizeable individual $(\geq 40 \mathrm{~cm}$ diameter at reference height) of $M$. excelsa, five of $K$. anthotheca and none of B. huillensis (Ahrends et al., 2010). In the early 200os logging shifted to species such as Millettia stuhlmannii (mpangapanga) and Pterocarpus angolensis 

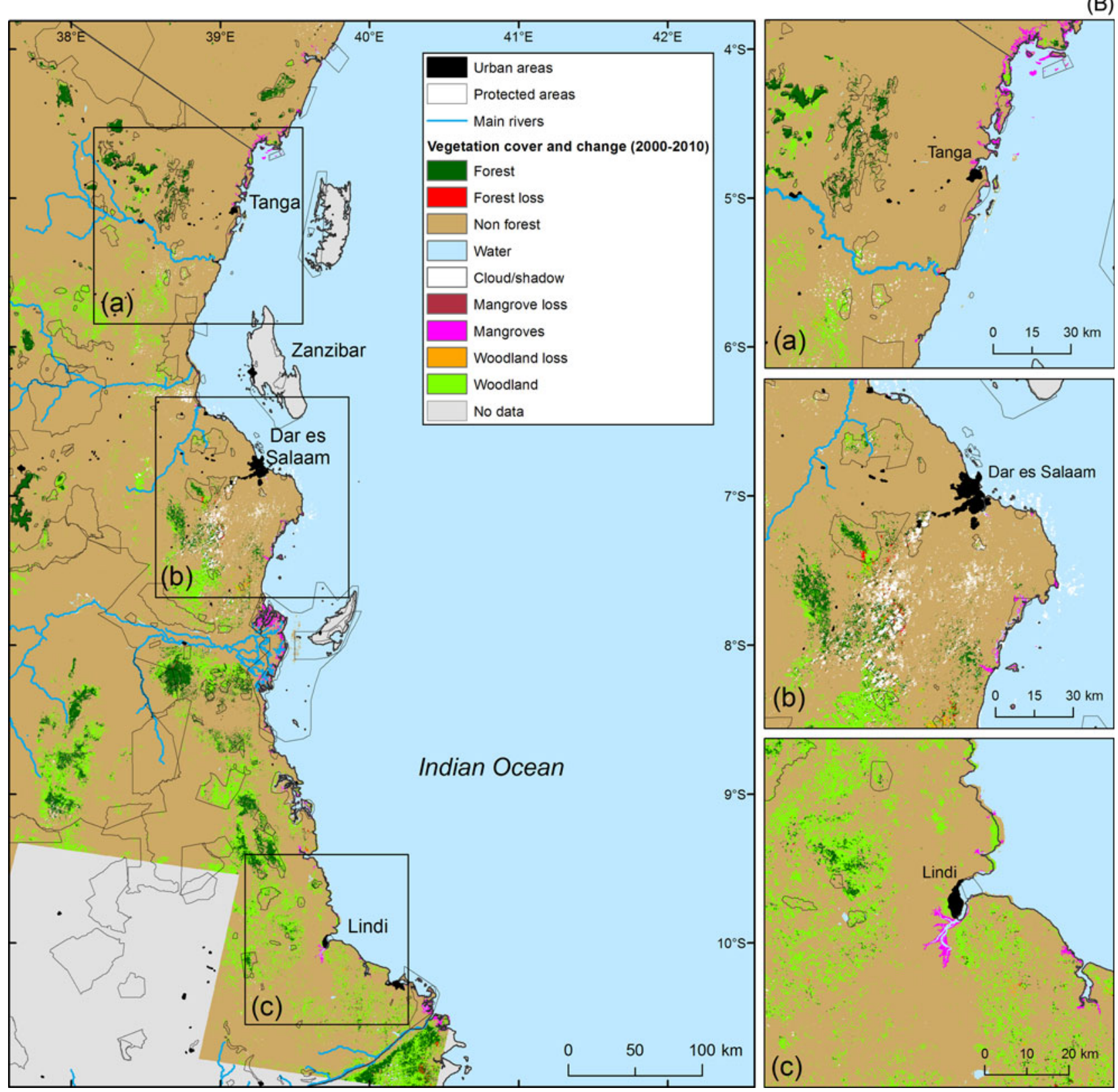

(B)

FIG. 1 (continued)

(mninga; Near Threatened; Milledge et al., 2007), which are now also becoming scarce (Sulle, 2013). Surveys since 2012 in southern Tanzania (Abdalah et al., 2012; authors, pers. obs.) have shown that as the availability of desired timber species has declined, loggers have exploited lower quality timber species; for example, Brachystegia spiciformis (mrihi), Baphia kirkii (mkuruti; Vulnerable) and the exotic mango Mangifera indica (mwembe; Schaafsma et al., 2012, 2014). Furniture makers in Dar es Salaam and the surrounding villages are now also using exotic Eucalyptus and Pinus from montane plantations, which was not the case during the baseline period. Where high-value timbers are still being used, timber dealers and furniture manufacturers often state (not always truthfully) that the timber is sourced from northern Mozambique, where supplies remain plentiful (Sulle, 2013).

\section{Conservation response}

The baseline 1995 protected forest area network for the coastal districts comprised 159 reserves, 152 of which were state managed: two Game Reserves, one Marine Reserve, 128 National Forest Reserves, 21 Local Authority Forest Reserves and seven Village Land Forest Reserves (Supplementary Table S4). During 1995-2014 the total 

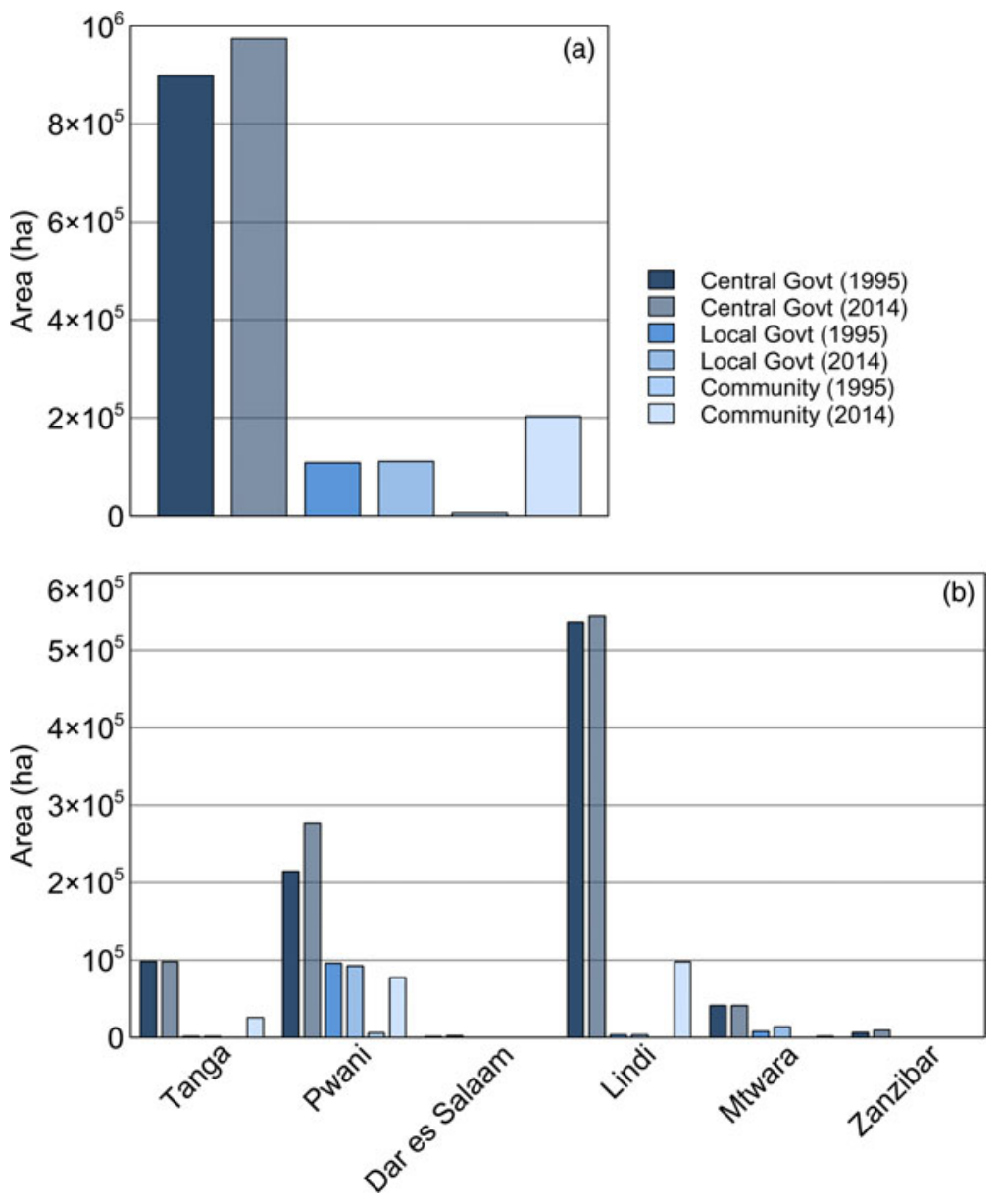

FIG. 2 Area of reserved forest habitats in the Tanzanian coastal regions (Fig. 1) in 1995 and 2014, (a) by reserve type and (b) by region.

area of reserved lands increased by $22 \%$, from $1,013,905$ to 1,233,646 ha (Fig. 2; Supplementary Tables $\mathrm{S}_{4} \& \mathrm{~S}_{5}$ ).

The increase in state protected areas is modest and driven mainly by the creation of Zaraninge Local Authority Forest Reserve; the upgrading of Jozani Forest Reserve and Saadani Game Reserve to National Parks (2004 and 2005), with the latter expanded through the inclusion of the former Mkwaja private ranch; the upgrading of Pemba Island's Ngezi Forest Reserve to a Nature Reserve (2012; Siex, 2011); and the declaration of Kiwengwa-Pongwe Forest Reserve (2013) on Unguja. On Mafia Island the mlola coastal forest is protected in Mafia Island Marine Park and a Local Authority Forest Reserve. Rondo Forest Reserve (14,00o ha) is also in the process of being upgraded to Nature Reserve status. By comparison, there have been significant increases in the area designated as community managed reserves, with at least 141 new Village Land Forest Reserves created, mainly in Pwani (55), Lindi (51) and Tanga (31) regions (Fig. 2). More are proposed, although the general tendency is for each village to set aside only one reserve within the village land area.

Reserves in Tanzania's coastal areas occupy the following hierarchy in terms of the de jure strictness of management and use restrictions: National Parks, Game Reserves, Nature Reserves, Marine Reserves, National Forest Reserves and
Local Authority Forest Reserves. Village Land Forest Reserves, which are under the direct management of local villages (Blomley et al., 2008; Kashaigili et al., 2011), allow sustainable use to support the livelihoods of local people, as do Wildlife Management Areas (WWF, 2014). The management effectiveness of 115 sites across the coastal forest region assessed between 2003 and 2015 (mainly during 2011-2015) was assessed using the METT tool. The overall mean percentage score for the 115 sites was $46.5 \pm$ SE $1.4 \%$, with central government-run National Parks and Game Reserves scoring highest (61.1 \pm SE 5.7\%; $n=3)$, followed by village-managed Village Land Forest Reserves (54.0 $\pm 1.3 \% ; n=47)$, local authority-managed Forest Reserves (43.6 $\pm 6.2 \% ; n=5)$ and central governmentmanaged Forest Reserves (39.6 $\pm 2.5 \% ; n=50$; Fig. 3). Proposed reserves performed poorly $(43.3 \pm 1.0 \% ; n=10)$ but the quality of their management was no different from gazetted central government and local authority-managed Forest Reserves, emphasizing the poor management of the government sites. These findings are in line with METT scores calculated in the same period in Rovuma and Udzungwa forest landscapes (WWF, 2013).

The components of management effectiveness developed by the IUCN World Commission on Protected Areas 

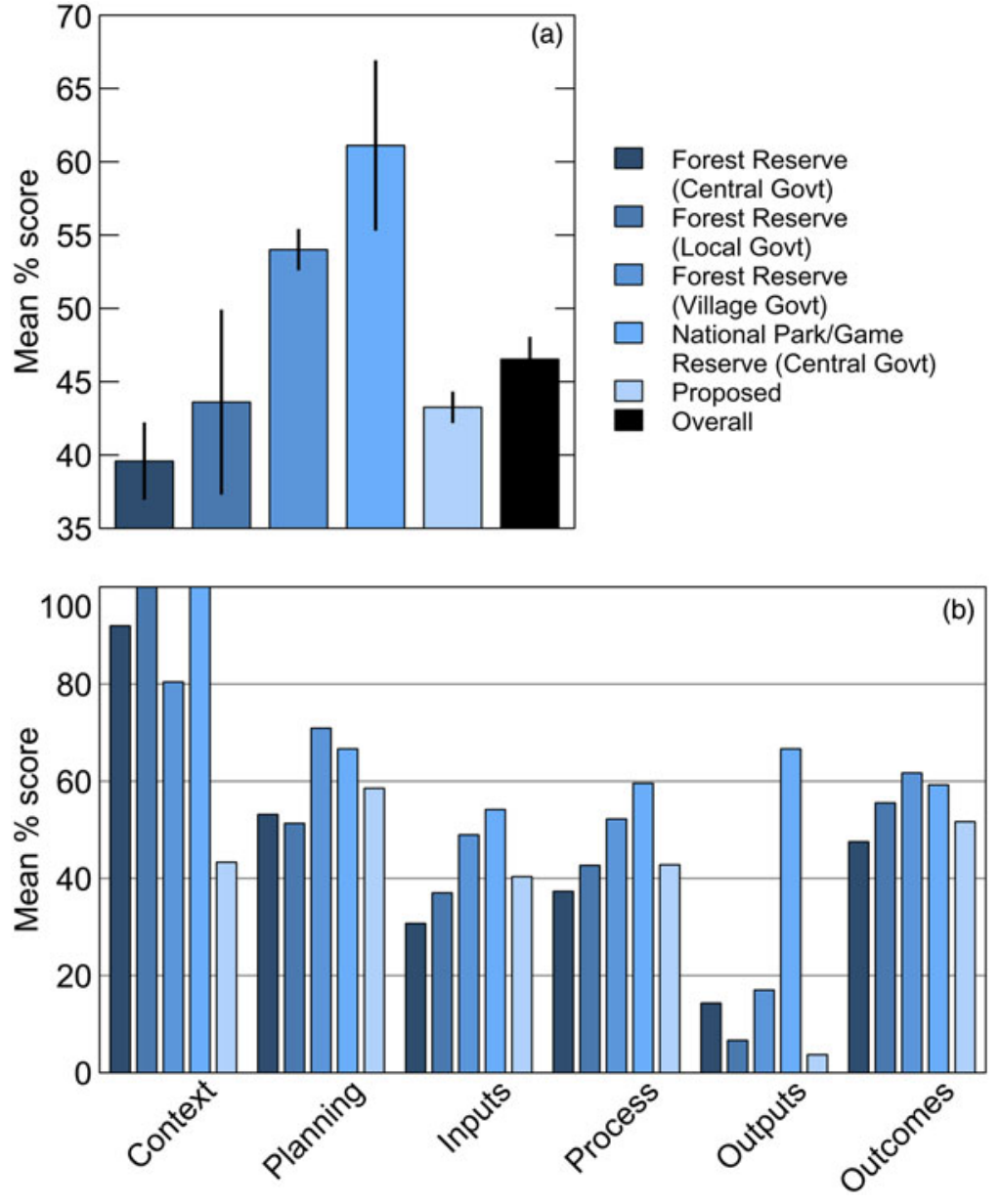

FIG. 3 (a) Mean percentage ( \pm SE) Management Effectiveness Tracking Tool (METT) scores for various categories of reserve (122 reserves in total) in the coastal regions of Tanzania and Zanzibar (Fig. 1), and (b) disaggregated by the World Commission on Protected Areas framework components of management effectiveness.
(Hockings et al., 2006) facilitate comparison of various facets of management. Higher scoring reserve types also score well across various management components, with the greatest difference being in the outputs category (i.e. the activities undertaken to achieve conservation outcomes; Fig. 3). Lower scores in planning and inputs are consistent with the prior knowledge that central and local government-managed Forest Reserves are under-resourced (e.g. lack of management and work plans, regulations, law enforcement, staff, training, budget; Kashaigili et al., 2011). However, there is little variation in scores for outcomes between reserve types (Fig. 3).

Despite an apparent lack of outputs, Village Land Forest Reserves perform well across all other elements of management (Fig. 3). The nature of these reserves (i.e. community managed) may render their higher METT scores an artefact of survey design, as the involvement of local and indigenous people in management is a key scoring element in the survey. However, our results show that the Village Land Forest Reserves in coastal Tanzania score higher in most areas of management effectiveness compared with other forest reserves, including in the formulation of goals and objectives, resource use and regulation, and conservation and community benefits, which is indicative of more effective management overall.

\section{Discussion}

We provide updated information on the biological values, protected area network and threats in the Tanzanian component of a global biodiversity hotspot, showing that the state of habitats has declined since 1995, although species values remain similar according to available data. Pressures on habitat and some valuable species are increasing and spreading. However, action to address the challenges is also increasing and there are enhanced efforts to bring local communities into the framework as managers of the resources and beneficiaries from their sustainable use.

An estimated 90\% of Tanzania's energy is provided by wood fuel (Schaafsma et al., 2012). Charcoal is the largest source of household energy in urban areas, being readily available, affordable and easy to produce, transport, distribute and store. During 2001-2007 the proportion of households in Dar es Salaam using charcoal for cooking increased from 47 to $71 \%$ (the population of the city had 
increased to $>4$ million by 2012). Charcoal production benefits local people who participate in cutting and burning trees, transporting bagged charcoal, selling it in towns, and exporting it to other countries. It is the primary source of cash income to some rural villages, and rivals agriculture as the main livelihood-sustaining activity (Schaafsma et al., 2012), especially in areas in the so-called charcoal zone around Dar es Salaam; in 2007 it was estimated to be worth c. USD 256 million per year (CAMCO, 2007).

Reliable data on charcoal harvesting are difficult to obtain. Surveys in 2012 indicated that most charcoal production was illegal but that charcoal bought by traders for transportation to urban centres was 'legalized' after the fact by using transit permits for charcoal that had been purchased earlier (Abdalah et al., 2012). Most traders transport more charcoal than is permitted by their harvest licenses, filling bags to more than the $56 \mathrm{~kg}$ allowed by law, sometimes to almost $100 \mathrm{~kg}$ (Abdalah et al., 2012). Another ploy used to circumvent the law is to transport bags past checkpoints by bicycle or motorcycle, as these are allowed to pass without declaration (Abdalah et al., 2012; Sulle, 2013).

Timber harvesting is another major threat to these forests. Improved infrastructure, including the opening of the Mkapa Bridge over the Rufiji River in 2003, has facilitated increased harvesting in southern coastal forests to supply Dar es Salaam (Milledge et al., 2007). Since the opening of the Unity Bridge over the Ruvuma River, which connects Mozambique to Tanzania, transportation of timber has become easier and Mozambique is now a major supplier of hardwood to Dar es Salaam. Some Tanzanian timber is transported to Mozambique and then re-exported to Tanzania, to secure transport permits to Dar es Salaam (Sulle, 2013).

According to Ministry of Natural Resources and Tourism export data, the annual export of sawn wood to China increased to a high of 8,950 $\mathrm{m}^{3}$ in 2007 and was $7,700 \mathrm{~m}^{3}$ in 2011; Baphia kirkii comprised $30 \%$ of the total in 2007 and $65 \%$ in 2011 (Sulle, 2013). Data from the United Nations Comtrade database on declared timber exports from Tanzania indicate that India and Kenya may now import more timber than China (Sulle, 2013). In 2011 India reportedly imported USD $>12$ million in wood products from Tanzania, whereas China imported only USD 2.7 million. The increasing scarcity of available forest for harvesting is indicated by a decrease in the size of planks for sale at local markets in Tanzania. During 2009-2011 there was a downward trend in plank size, especially for hardwood species, so that more planks could be harvested from a single tree, and immature trees could also be harvested (Schaafsma et al., 2014). During the same time-frame the price increased by $36 \%$, significantly above the rate of inflation.

In coastal districts all Forest Reserves under central government ownership were devolved to district levels in the 1970s, with few staff or funds for management. The World Bank/International Monetary Fund structural adjustment programme implemented in Tanzania from 1986 (Agrawal et al., 1993) resulted in a significant reduction in staffing across the forestry sector. The central government-owned reserves were allocated no resources for management, from either central or local government. The reserves therefore became effectively open-access land, used for timber harvesting and charcoal production. The parlous state of reserve management is apparent in the management effectiveness results (Fig. 3), where Central Government National Forest Reserves have the lowest level of management effectiveness even though they are the most numerous (129 of 257 reserves) and have the greatest area (858,724 of 1,281,101 ha).

The expansion of community-managed Village Land Forest Reserves has been driven by changes in government policy, starting in 1998 with a new Forest Policy (URT, 1998; Blomley et al., 2008). This policy change was bolstered by a new Forest Act in 2002 (URT, 2002) and Guidelines on Participatory Forest Management (URT, 2003). Village Land Forest Reserves provide local control over forest resources, and thus local people can benefit from their management of forest resources. The effectiveness of Village Land Forest Reserves in coastal regions is also evident elsewhere in Tanzania (Knights et al., 2014). However, these reserves only cover a small portion of the reserve network.

Benefits to local communities from Village Land Forest Reserves include logging, sustainable charcoal production and climate mitigation payments under REDD+. Experiences from the Kilwa district, in Lindi region, show that communities can derive significant revenues from logging of high-value timber species, especially if that timber is certified using international standards (e.g. the Forest Stewardship Council Group Certification scheme; Ball \& Makala, 2014; Kalonga et al., 2015). Communities in Kisangi, Kikole, Liwiti, Nainokwe and Nanjirinji villages in the Kilwa district had benefited from TZS $>60$ million (c. USD 10,000) by the end of 2012, compared with zero income prior to certification in 2009 (Khatun et al., 2015), with the income increasing to USD $>300,000$ per annum during 2013-2014 (authors, pers obs).

In conclusion, there have been substantive losses of habitat in the coastal forest since 1995, and rapid urbanization, industrialization and population growth mean that pressures continue to increase. Tanzania's economy is expected to grow, following the discovery of natural gas reserves worth six times the country's gross domestic product. This will bring challenges but also opportunities for conservation. Conservation programmes in the Tanzanian coastal forests have responded flexibly to new pressures and opportunities, and progress has been made with the expansion of the reserve network, payment for ecosystem services schemes, community co-management and sustainable extraction. However, continued commitment from many 
stakeholders is required to ensure that the unique biological values survive and that the necessary materials to support livelihoods in this developing country continue to be delivered from these forests.

\section{Acknowledgements}

We thank Nicholas Kinyau, Jasper Makala, Simon Moshi, Jumanne Abdallah, Kahana Lukumbuza, Josephine Urock, Simon Milledge, Zawadi Mbwambo, Richard Komba, Paul Harrison, James Lazier and Andrew Williams for their contributions to the data used here. This paper was partly derived from the work of the UNDP GEF funded project 'Extending the Coastal Forest Protected Area Sub-system in Tanzania'. April Eassom and Yara Shennan-Farpon at UNEP-WCMC prepared the maps of forest cover change using the dataset of Hansen et al. (2013).

\section{References}

Abdalah, J.M., Lukumbuzya, K., Kabadi, G. \& Urock, J. (2012) Economic Valuation of Coastal Forests of Tanzania. UNDP GEF Coastal Forests Project, WWF Tanzania, Dar es Salaam, Tanzania.

Agrawal, N., Ahmed, Z., Mered, M. \& Nord, R. (1993) Structural Adjustment, Economic Performance, and Aid Dependency in Tanzania. Working paper of The World Bank and International Monetary Fund. Http://www-wds.worldbank.org/servlet/WDS ContentServer/WDSP/IB/1993/10/o1/ooooo9265_3961005101627/ Rendered/PDF/multiopage.pdf [accessed 14 September 2015].

Ahrends, A. (2005) Patterns of degradation in lowland coastal forests in Coast Region, Tanzania. MSc thesis. University of Greifswald, Germany.

Ahrends, A., Burgess, N.D., Milledge, S.A.H., Bulling, M.T., Fisher, B., Smart, J.R.C. et al. (2010) Predictable waves of sequential forest degradation and biodiversity loss spreading from an African city. Proceedings of the National Academy of Sciences of the United States of America, 107, 14556-14561.

Azeria, E.T., Sanmartín, I., Ås, S., Carlson, A. \& Burgess, N.D. (2007) Biogeographic patterns of the East African coastal forest vertebrate fauna. Biodiversity and Conservation, 16, 883-912.

B ALL, S. \& MaKala, J. (2014) Making REDD+ Work for Communities and Forests: Three Shared Lessons for Project Designers. IIED, London, UK. Http://pubs.iied.org/17211IIED [accessed 14 September 2015].

Belokurov, A., Besançon, C., Pavese, H., Burgess, N.D., Dudley, N., Stolton, S. et al. (2009) New resources for assessing the effectiveness of management in protected areas. Oryx, 43, 14.

Blomley, T., Pfliegner, K., Isango, J., Zahabu, E., Ahrends, A. \& Burgess, N.D. (2008) Seeing the wood for the trees: an assessment of the impact of participatory forest management on forest condition in Tanzania. Oryx, 42, 380-391.

Broadley, D.G. (2003) The reptiles of the East African Coastal Mosaic. Biodiversity Foundation for Africa. Http://www. biodiversityfoundation.org/documents/s19.pdf [accessed 14 September 2015].

Burgess, N.D., Bahane, B., Clairs, T., Danielsen, F., Dalsgaard, S., FUnder, M. et al. (2010) Getting ready for REDD+ in Tanzania: a case study of progress and challenges. Oryx, 44, 339-351.
Burgess, N.D. \& Clarke, G.P. (eds) (2000) The Coastal Forests of Eastern Africa. IUCN Forest Conservation Programme, Gland, Switzerland, and Cambridge, UK.

Burgess, N.D., Clarke, G.P. \& Rodgers, W.A. (1998) Coastal forests of eastern Africa: status, endemism patterns and their possible causes. Biological Journal of the Linnean Society, 64, 337-367.

Burgess, N.D., Doggart, N., Doody, K., Perkin, A., Negussie, G. \& Sumbi, P. (2003) New information on the lowland coastal forests of eastern Africa. Oryx, 37, 280-281.

Burgess, N.D., Gordon, I., Salehe, J., Sumbi, P., Doggart, N., Rodgers, A. \& Clarke, P. (2004) Coastal forests of eastern Africa. In Hotspots Revisited: Earth's Biologically Richest and Most Endangered Terrestrial Ecoregions, 2nd edition (eds R.A. Mittermeier, P. Robles-Gil, M. Hoffmann, J.D. Pilgrim, T.M. Brooks, C.G. Mittermeier et al.), pp. 231-239. Cemex, Mexico. Burgess, N.D., Loucks, C., Stolton, S. \& Dudley, N. (2007) The potential of forest reserves for augmenting the protected area network in Africa. Oryx, 41, 151-159.

CAMCO (2007) Charcoal situation analysis in Tanzania. Report for WWF Tanzania, Dar es Salaam, Tanzania.

Clarke, G.P., Burgess, N.D., Mbago, F.M., Mligo, C. Mackinder, B. \& Gereau, R.E. (2011) Two 'extinct' trees rediscovered near Kilwa, Tanzania. Journal of East African Natural History, 100, 133-140.

Couvreur, T.L.P., Gereau, R.E., Wieringa, J.J. \& Richardson, J.E. (2006) Description of four new species of Monodora and Isolona (Annonaceae) from Tanzania and an overview of Tanzanian Annonaceae diversity. Adansonia, 28, 243-266.

Dawson, S.E. \& Gereau, R.E. (2010) New species of Aidia and Polysphaeria (Rubiaceae) from East Africa. Novon, 20, 256-264.

Gereau, R.E., Kajuni, A.R., Davenport, T.R.B. \& Ndangalasi, H. J. (2012) Lake Nyasa Climatic Region Floristic Checklist. Missouri Botanical Garden, St. Louis, USA.

Gereau, R.E., Kariuki, M., Ndang'ang'a, P.K., Werema, C. \& Muoria, P. (2014) Biodiversity Status and Trends in the Eastern Arc Mountains and Coastal Forests of Kenya and Tanzania Region, 2008-2013. BirdLife International-Africa Partnership Secretariat, Nairobi, Kenya.

Godoy, F.L., Tabor, K., Burgess, N.D., Mbilinyi, B.P., Kashaigili, J.J. \& S TEININGER, M.K., (2011) Deforestation and $\mathrm{CO}_{2}$ emissions in coastal Tanzania from 1990 to 2007. Environmental Conservation, $39,62-71$.

Hansen, M.C., Potapov, P.V., Moore, R., Hancher, M., Turubanova, S.A., Tyukavina, A. et al. (2013) High-resolution global maps of 21st-century forest cover change. Science, 342, $850-853$.

Harrison, P., Lazier, J. \& Williams, A. (2011) Reserves Network and Management Effectiveness in the Coastal Forests of Tanzania. Unpublished UNDP GEF project report.

Hockings, M., Stolton, S., Leverington, F., Dudley, N. \& Courrau, J. (2006) Evaluating Effectiveness: A Framework for Assessing Management Effectiveness of Protected Areas. 2nd edition. IUCN, Gland, Switzerland, and Cambridge, UK.

Howell, K.M., Msuya, C.A., Mligo, C., Werema, C., Kihaule, P., Honorati, M.K. \& Suleiman, H.O. (2011) Biodiversity Surveys of Poorly Known Coastal Forests of Southeastern Tanzania and Zanzibar. Unpublished UNDP GEF project report.

IUCN (1994) IUCN Red List Categories. Prepared by the IUCN Species Survival Commission. IUCN, Gland, Switzerland.

IUCN (2012) IUCN Red List Categories and Criteria: Version 3.1. 2nd edition. Gland, Switzerland, and Cambridge, UK.

Kalonga, S.K., Midtgaard, F. \& Eid, T. (2015) Does forest certification enhance forest structure? Empirical evidence from 
certified community-based forest management in Kilwa District, Tanzania. International Forestry Review, 17, 182-194.

Kashaigili, J.J., Nzunda, E.F., Sirima, A., Shirima, D., Mwamakimbulla , R. \& Mkumbo, P.J. (2011) Spatial Planning Baseline Focusing on the Coastal Forests of Tanzania for the GEF Coastal Forest Project. Unpublished UNDP GEF project report.

Khatun, K., Gross-Camp, N., Corbera, E., Martin, A. \& Ball, S. (2015) When Participatory Forest Management makes money: insights from Tanzania on governance, benefit sharing and implications for REDD+. Environment and Planning $A$, in press.

Knights, K., Cuadros, I., Zamora, C., Coad, L., Leverington, F., O'Connor, B. et al. (2014) A preliminary assessment of protected area management within the WWF 'Coastal East Africa' priority place, Eastern Africa. Parks, 20, 77-88.

Leverington, F., Costa, K.L., Courrau, J., Pavese, H., Nolte, C., MArR, M. et al. (2010) Global Study Into Protected Area Management Effectiveness: Updated Edition for CBD COP1o, Japan, October 2010. University of Queensland, Australia.

Lopa, D., Mwanyoka, I., Jambiya, G., Massoud, T., Harrison, P., Ellis-Jones, M. et al. (2012) Towards operational payments for water ecosystem services in Tanzania: a case study from the Uluguru Mountains. Oryx, 46, 34-44.

Malugu, I. (2012) Perspectives in Resource Use Conflicts. Management Challenges for Pugu and Kazimzumbwi Coastal Forests, Tanzania. Lambert Publishing House, Saarbrücken, Germany.

Milledge, S.A.H., Gelvas, I.K. \& Ahrends, A. (2007) Forestry, Governance and National Development: Lessons Learned from a Logging Boom in Southern Tanzania. TRAFFIC East/Southern Africa/Tanzania Development Partners Group/Ministry of Natural Resources of Tourism, Dar es Salaam, Tanzania.

Mittermeier, R.A., Robles-Gil, P., Hoffmann, M., Pilgrim, J.D., Brooks, T.M., Mittermeier, C.G. et al. (2004) Hotspots Revisited: Earth's Biologically Richest and Most Endangered Terrestrial Ecoregions. 2nd edition. Cemex, Mexico.

Salehe, J., Burgess, N.D., Springer, J., Sumbi, P. \& Younge, A. (2006) The Eastern African Coastal Forests Ecoregion: A Strategic Framework for Action 2005-2025. WWF Tanzania Programme Office, Dar es Salaam, Tanzania.

Schaafsma, M., Burgess, N.D., Swetnam, R.D., NGaga, Y.M., Turner, R.K. \& Treue, T. (2014) Market signals of unsustainable and inequitable forest extraction: assessing the value of illegal timber trade in the Eastern Arc Mountains of Tanzania. World Development, 62, 155-168.

Schatasma, M., Morse-Jones, S., Posen, P., Swetnam, R.D., Balmford, A., Bateman, I.J. et al. (2012) Towards transferable functions for extraction of Non-timber Forest Products: a case study on charcoal production in Tanzania. Ecological Economics, 80, 48-62.

Shemdoe, R.S. \& Abdalah, J.M. (2011) Socio-Economic Baseline Surveys for Selected Coastal Forest Landscapes in Tanzania. Consultancy report submitted to WWF Tanzania country office, Dar es Salaam, Tanzania.

Siex, K.S. (2011) Protected Area Spatial Planning for Unguja and Pemba Islands, Zanzibar. Final consultancy report submitted to WWF from Wildlife Conservation Society.

Sulle, E. (2013) A Rapid Assessment of the Illegal Timber Trade Across the Ruvuma River on the Tanzania-Mozambique Border. TRAFFIC East/Southern Africa-East Africa Sub-Regional Office.

Tabor, K., Kashaigili, J., Mbilyni, B. \& Wright, T.M. (2015) Forest Cover and Change for Eastern Arc Mountains and Coastal Forests of Tanzania and Kenya c. 2000 to c. 2010. Conservation International, Arlington, USA.
Tabor, K., Mbilyni, B., Kashaigili, J., Steininger, M.K. \& Burgess, N.D. (2010) A multi-date baseline forest estimate for the 1990 s and 2000 and habitat assessment within protected areas for the coastal forests of Tanzania and Kenya. Journal of East African Natural History, 99, 19-45.

Treue, T., Ngaga, Y.M., Meilby, H., Lund, J.F., Kajembe, G., Iddi, S. et al. (2014) Does participatory forest management promote sustainable forest utilisation in Tanzania? International Forestry Review, 16, 23-38.

UndP-GeF (United Nations Development Programme Global Environment Facility) (2008) Extending the protected areas of coastal forests sub-system. Funding proposal from United Republic of Tanzania (Ministry of Natural Resources and Tourism, Forestry and Beekeeping Division) to UNDP-GEF, Dar es Salaam, Tanzania.

UNDP, GOT \& ESRC (2013) Tanzania Human Development Report 2014: Economic Transformation for Human Development. UNDP, Economic and Social Research Council \& Government of Tanzania, Dar es Salaam, Tanzania.

URT (United Republic of Tanzania) (1998) National Forest Policy. Ministry of Natural Resources and Tourism, Forestry and Beekeeping Division, Dar es Salaam, Tanzania.

URT (United Republic of Tanzania) (2002) The Forest Act, No. 2 of 7 th June 2002. Ministry of Natural Resources and Tourism, Dar es Salaam, Tanzania.

URT (United Republic of Tanzania) (2003) Framework for Participatory Forest Management. Ministry of Natural Resources and Tourism, Dar es Salaam, Tanzania.

Wegner, G., Howell, K.M., Burgess, N.D., Rubio, P. \& Fanning, E. (eds) (2006) Mtwara Reconnaissance Project: A Reconnaissance to Prioritise Biological Knowledge for Community Conservation Initiatives 2005. Http://coastalforests.tfcg.org/pubs/Frontier\% 20Mtwara\%20Coastal\%2oForests\%20Science\%2oReport_2005.pdf [accessed 18 September 2015].

Wegner, G., Howell, K.M., Davenport, T.R.B. \& Burgess, N.D. (2009) The forgotten coastal forests of Mtwara, Tanzania: a biologically impoverished and yet important ecosystem. Journal of East African Natural History, 98, 167-209.

WWF (2011) Threatened Spaces, Disappearing Species: The Forests and Woodlands of the Coastal East African Region. WWF Coastal East Africa Initiative, Dar es Salaam, Tanzania.

WWF (2013) METT Baselines for Rovuma and Udzungwas Landscapes. WWF Tanzania Country Programme Office, Dar es Salaam, Tanzania.

WWF (2014) Tanzania's Wildlife Management Areas: A 2012 Status Report. WWF, Dar es Salaam, Tanzania.

\section{Biographical sketches}

NDB, IM, PS, AK and AK have worked in the coastal forests of Tanzania for more than 20 years, undertaking various kinds of research and practical conservation work together with government staff and community members. They have worked within both government agencies and NGOs, and with UN agencies promoting conservation and sustainable use. BM, JK, KT, TMW, LC, KK, JC, AA and RN have undertaken various technical analyses of forest disturbance and forest cover change, and assessment of the conservation status of reptiles and plants. Collectively the authors have considerable accumulated knowledge about these forests, their values, the conservation challenges they face and the changes that have occurred there during the past 2 decades. 